\title{
Hydrolysis of Cellulose from Oil Palm Empty Fruit Bunch using Aspergillus niger
}

\author{
Sri Sugiwati ${ }^{1, *}$, Suaidah Suaidah ${ }^{1 *}$, Eka Triwahyuni $^{1}$, Muryanto Muryanto ${ }^{1}$, \\ Yosie Andriani ${ }^{2}$ and Haznan Abimanyu ${ }^{1}$ \\ ${ }^{1}$ Research Center for Chemistry, Indonesian Institute of Sciences, Kawasan Puspiptek Serpong, \\ Tangerang 15314, Indonesia \\ ${ }^{2}$ Institute of Marine Biotechnology, University Malaysia Terengganu, Mengabang Telipot 21030, \\ Kuala Nerus, Terengganu, Malaysia
}

\begin{abstract}
Oil palm empty fruit bunch (OPEFB) constitutes a great source of lignocellulosic biomass, mainly comprising of $66.97 \%$ of holocellulose (cellulose and hemicellulose) and $24.45 \%$ of lignin. This present work aimed to hydrolyze cellulose present in OPEFB to form glucose with the aid of Aspergillus niger. A. niger is a type of filamentous fungi able to produce cellulase, a multi-enzyme complex consisting of an endoglucanase, exoglucanase, and $\beta$-glucosidase, able to converting cellulose into glucose. The glucose produced is then fermented to produce bioethanol. The present study compared hydrolytic activity of cellulose between OPEFB with pretreatment using $\mathrm{NaOH} 10 \%$ and OPEFB without pretreatment, concerning temperature, $\mathrm{pH}$, and hydrolysis time. The concentration of reducing sugar derived from cellulosic hydrolysis was determined by using a glucose assay of 3.5-dinitrosalicylic acid. The results showed that the optimum temperature for hydrolysis of cellulose OPEFB (pretreated and untreated) was at $40{ }^{\circ} \mathrm{C}$ and the optimum $\mathrm{pH}$ was 5.0 for OPEFB-untreated and 5.5 for OPEFB-pretreated. Hydrolysis of cellulose at $40{ }^{\circ} \mathrm{C}$ and $3 \mathrm{~d}$ yielded reducing sugar $13.01 \mathrm{mg} \mathrm{mL}^{-1}$ and $1.16 \mathrm{mg} \mathrm{mL}^{-1}$ for OPEFB-untreated and OPEFB-pretreated, respectively.
\end{abstract}

Keywords: $2^{\text {nd }}$ bioethanol generation, biomass, cellulose hydrolysis, lignin, renewable energy

\section{Introduction}

Bioethanol constitutes an advanced source of renewable energy which may potentially replace the use of fossil fuel. Ethanol for transportation fuel can contribute to the alleviation of the greenhouse effect in the atmosphere [1]. Agricultural and forestry biomass can be an imperative source since they are rich in cheap lignocellulose which is potentially used as a substrate for fermentation in producing bioethanol [2].

Oil Palm Empty Fruit Bunches (OPEFB) is considered as a residual problem derived from palm oil production, and it is present in a large quantity. OPEFB contains a significant portion of cellulose and hemicellulose (66.97\%), and lignin $(24.45 \%)$ [3]. Cellulose and hemicellulose are possible to convert into fermentable sugars.

\footnotetext{
*Corresponding author: sri_sugiwati@yahoo.co.id
} 
Hydrolysis process becomes of a foremost factor in bioconversion of lignocellulose into bioethanol. Commonly, the stage is performed using two methods: acid and enzymatic hydrolysis using cellulases [4]. Acid hydrolysis commonly used sulphuric and hydrochloric acids as catalysts for hydrolysis of lignocellulosic biomass [5]. Acid hydrolysis often uses either concentrated acids or diluted acids. When concentrated acid is used, it induces corrosion in the instruments, while diluted acid may need a higher temperature to decompose hemicellulose which leads to the formation of toxic compounds such as furfural and 5-hydroxymethyl furfural (HMF). Presence of these noxious components is harmful to the growth of yeasts and then retards fermentation, enabling to alleviate the production of ethanol [6]. On the other hand, an enzymatic process for decomposing cellulose can be more satisfying in comparison with inorganic acids, considering that enzyme catalytic reaction works at the specific substrate and can be performed in mild process conditions [4].

Enzymatic hydrolysis of cellulosic biomass is carried out using cellulase which is a multienzyme complex consisting of Carboxymethyl cellulase (CMCase) or endo- $\beta$ glucanase (EC 3.2.1.4), exo- $\beta$-glucanase (EC 3.2.1.91) and $\beta$-glucosidase (EC 3.2.1.21) [7]. These enzymes worked synergistically to hydrolyze cellulose into glucose [8].

Filamentous fungi, particularly Aspergillus niger [van Tieghem, 1867] and Trichoderma reesei [Simmons, 1977] have attracted most attention due to their high cellulase productivity and safe use in industry [9]. In this work, enzyme-induced hydrolysis of OPEFB involved local isolate A. niger InaCC F98, obtained from Indonesian Culture Collection (InaCC), Research Center for Biology, Indonesian Institute of Sciences. A. niger has been reported capable of hydrolyzing cellulose present in OPEFB since this species enabled to produce cellulase. Prior to hydrolysis, OPEFB used as substrate was pre-treated using $\mathrm{NaOH} 10 \%$, while the result was then compared with the untreated substrate. Hydrolytic product was evaluated according to the content of reducing sugar using the 3,5dinitrosalisilic acid method [10].

\section{Materials and methods}

\subsection{Materials}

Oil palm empty fruit bunches (OPEFB) were collected from a palm oil plantation in Palembang, Indonesia. A local fungal isolate of A. niger InaCC F98 was obtained from the Indonesian Culture Collection (InaCC), Research Center for Biology Indonesian Institute of Sciences, Cibinong, Bogor. Potato Dextrose Agar (PDA), sodium citrate buffer, dinitrosalicylic acid, sodium potassium tartrate. The experimental parameters included temperature, $\mathrm{pH}$, and hydrolysis time.

\subsection{Alkaline Pretreatment of OPEFB}

The alkaline pretreatment of OPEFB was conducted using a bench-scale reactor at the Research Center for Chemistry, Indonesian Institute of Sciences (LIPI). $500 \mathrm{~g}$ of OPEFB was heated with $2500 \mathrm{~mL}$ of $10 \% \mathrm{NaOH}$ solution at $150{ }^{\circ} \mathrm{C}$ for $30 \mathrm{~min}$. The pressure was controlled by 4 bar at early heating. After pretreatment, the substrate was pressed in order to separate solidity from liquid fraction. Furthermore, solidity fraction was neutralized until the $\mathrm{pH}$ of 7.0 and dried in the oven at $50{ }^{\circ} \mathrm{C}$ to $60{ }^{\circ} \mathrm{C}$ overnight [11]. 


\subsection{Regeneration of Aspergillus niger}

A. niger was grown on Potato Dextrose Agar (PDA) slants for $5 \mathrm{~d}$ at $28{ }^{\circ} \mathrm{C}$. Furthermore, the spores were harvested by scraping from PDA slants with $10 \mathrm{~mL}$ of distilled water to give spore suspension $\left(1 \times 10^{7}\right.$ spores $)$ for the inoculum of the hydrolysis process.

\subsection{Hydrolysis of oil palm empty fruit bunches}

Sample of $2.5 \mathrm{~g}$ each from OPEFB-untreated and alkali pretreated OPEFB was placed in $50 \mathrm{~mL}$ of $0.05 \mathrm{M}$ citrate buffer in $100 \mathrm{~mL}$ Erlenmeyer flask. Prior to the addition of the spore suspension of A. niger to the OPEFB-untreated and alkali pretreated OPEFB, the substrate and buffer mixture was autoclaved for $20 \mathrm{~min}$ at $121{ }^{\circ} \mathrm{C}$ to sterilize the medium and prevent contamination. After cooling, into each of these Erlenmeyer flasks was inoculated with $1 \mathrm{~mL}$ spore suspension $\left(10^{7}\right.$ spores) of A. niger InaCC F98 wich $5 \mathrm{~d}$ old. Furthermore, these Erlenmeyer flasks containing sterile substrate medium were incubated at $150 \mathrm{rad} \mathrm{s}^{-1}$ at defined condition were used to be optimized for $72 \mathrm{~h}$. Samples from each set were taken after $24 \mathrm{~h}, 48 \mathrm{~h}$, and $72 \mathrm{~h}$ and centrifuged for $10 \mathrm{~min}$ at $4{ }^{\circ} \mathrm{C}$. The reducing sugars content in the supernatant was measured using dinitrosalicylic acid (DNS) method [10].

To determine the optimal temperature, the hydrolysis process was performed at different temperatures $\left(30{ }^{\circ} \mathrm{C}, 35{ }^{\circ} \mathrm{C}, 40{ }^{\circ} \mathrm{C}\right.$, and $\left.45{ }^{\circ} \mathrm{C}\right)$ and an incubation time of $72 \mathrm{~h}$. The hydrolysis optimum $\mathrm{pH}$ was determined by adjusting the initial medium $\mathrm{pH}$ in range 4.0 to 6.5 using $1 \mathrm{mmol} \mathrm{L}^{-1} \mathrm{HCl}$ or $1 \mathrm{mmol} \mathrm{L}^{-1} \mathrm{NaOH}$. The hydrolysis process was performed at an incubation temperature of $40^{\circ} \mathrm{C}$ for $72 \mathrm{~h}$.

\section{Results and discussions}

In the present study, enzymatic hydrolysis of OPEFB with or without pre-treatment using $\mathrm{NaOH} 10 \%$ was compared. For hydrolysis, isolate A. niger InaCC F98 was applied for its role as producer of cellulase. To achieve optimum results, the hydrolytic process was performed at a variety of temperature of incubation, medium $\mathrm{pH}$, and time of hydrolysis.

\subsection{Effect of temperature on hydrolysis}

In this part, untreated and treated OPEFB was used at $5 \%$ in the citric buffer $(0.05 \mathrm{M}$; pH 4.5). The optimum temperature for hydrolysis of OPEFB-untreated and alkali-treated OPEFB was determined at different temperatures of $30^{\circ} \mathrm{C}$ to $45^{\circ} \mathrm{C}$ for $24 \mathrm{~h}, 48 \mathrm{~h}$ and $72 \mathrm{~h}$ of incubation. The content of reducing sugars obtained during the hydrolysis of OPEFB at different temperatures of incubation can be seen in Fig. 1 and Fig. 2. The results showed that the hydrolysis rate was increased with the increasing of temperature and incubation time of hydrolysis. Reducing sugars production at $30{ }^{\circ} \mathrm{C}$ and $35{ }^{\circ} \mathrm{C}$ ranged from $0.68 \mathrm{mg} \mathrm{mL}^{-1}$ to $0.93 \mathrm{mg} \mathrm{mL}^{-1}$ for OPEFB-untreated and $0.13-0.19 \mathrm{mg} \mathrm{mL}^{-1}$ for alkalitreated OPEFB after $72 \mathrm{~h}$ of incubation. The optimum yield was achieved at $40{ }^{\circ} \mathrm{C}$ for $72 \mathrm{~h}$ of incubation, resulting in reducing sugar of $13.01 \mathrm{mg} \mathrm{mL}^{-1}$ (OPEFB-untreated) and 1.16 $\mathrm{mg} \mathrm{mL}^{-1}$ (alkali-treated OPEFB).

The usage of temperature (above or below optimum level) significantly alleviated hydrolysis rate. The hydrolysis process of lignocelluloses proceeds at low temperature it would be desirable for industrial application because of less input of energy $[12,13]$. Optimum temperature in this study is lower than that found by Sridevi et al. [12], i.e., $50{ }^{\circ} \mathrm{C}$, in which they investigated the usage of the crude enzyme (cellulase) from A. niger 
for depolymerizing sawdust (native and treated). Production of reducing sugar in native and pretreated sawdust after $72 \mathrm{~h}$ incubation at $50{ }^{\circ} \mathrm{C}$ reached $5.4 \%$ and $14 \%$, respectively.

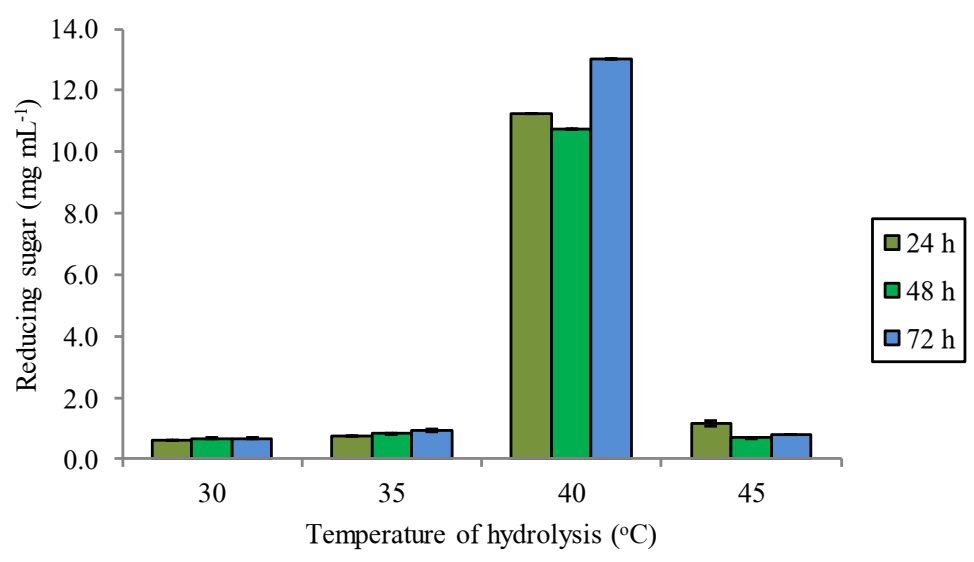

Fig. 1. Effect of temperature on hydrolysis of OPEFB-untreated using A. niger.

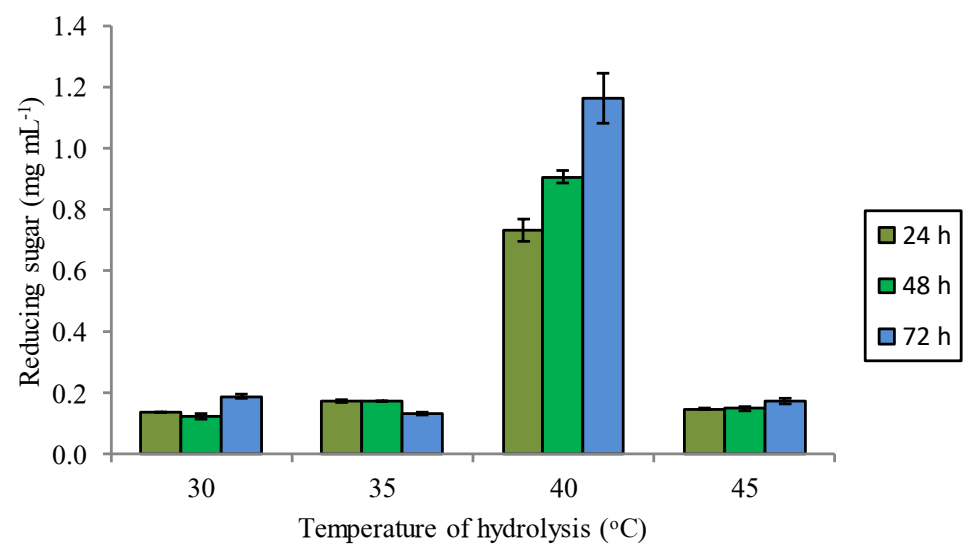

Fig. 2. Effect of temperature on hydrolysis of alkali-treated OPEFB using A. niger.

\subsection{Effect of $\mathrm{pH}$ on hydrolysis}

One of the imperative factors in the hydrolysis process is the $\mathrm{pH}$ of the medium since it could affect the growth of microorganisms. These inhibitions of microorganism's growth, therefore, affects the production of cellulase and reducing sugars during hydrolysis. The hydrolysis of OPEFB-untreated and alkali-treated OPEFB was carried out in the medium $\mathrm{pH}$ range 4.0 to 6.0 to obtain the optimum $\mathrm{pH}$ of hydrolysis. The effect of $\mathrm{pH}$ on the production of reducing sugars during the hydrolysis of OPEFB can be seen in Fig. 3 and Fig. 4. The results showed that reducing sugars content at the medium $\mathrm{pH} 4.0$ to $\mathrm{pH} 6.0$ after $72 \mathrm{~h}$ of incubation were a range of value of $0.74 \mathrm{mg} \mathrm{mL}^{-1}$ to $1.58 \mathrm{mg} \mathrm{mL}^{-1}$ for 
OPEFB-untreated and $0.17 \mathrm{mg} \mathrm{mL}^{-1}$ to $0.23 \mathrm{mg} \mathrm{mL}^{-1}$ for alkali-pretreated OPEFB, respectively.

The optimum $\mathrm{pH}$ value was observed at $\mathrm{pH} 5.0$ (OPEFB-untreated) and $\mathrm{pH} 5.5$ (alkalitreated OPEFB). Similarly, the level of $\mathrm{pH}$ was augmented by the former report of Sridevi et al. [12] for hydrolyzing alkali-treated sawdust using crude extract of cellulase from A. niger. In this regard, the $\mathrm{pH}$ of nutrient medium and substrate sigficantly contributed to the performance of fungi Aspergillus growth [14]. This is noteworthy that $\mathrm{pH}$ of the medium can properly promote changes in microbial morphology and secretion of cellulase [15]. The enzyme secretion is further important for the production of reducing sugar during hydrolysis.

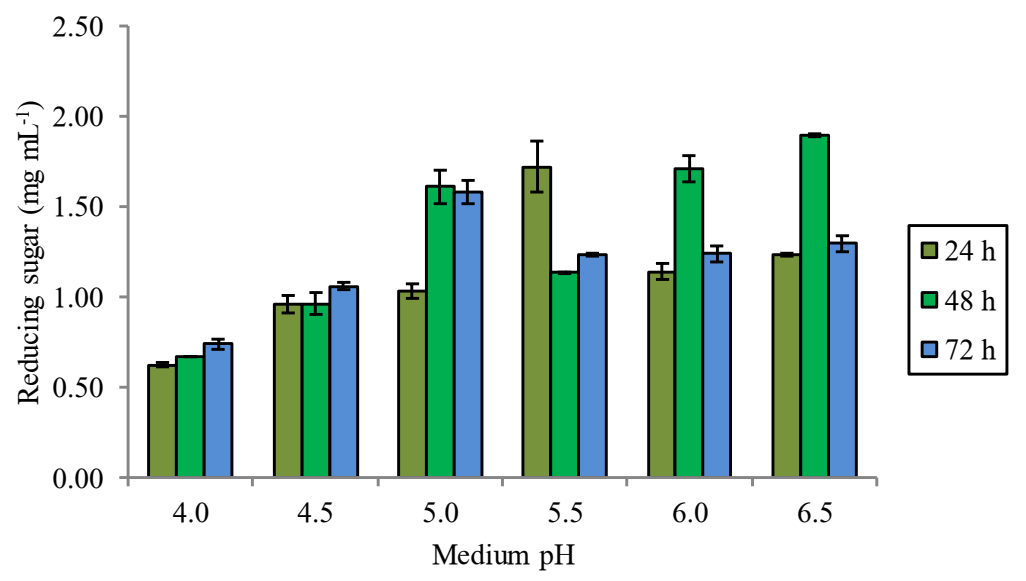

Fig. 3. Effect of medium $\mathrm{pH}$ on hydrolysis of OPEFB-untreated using A. niger.

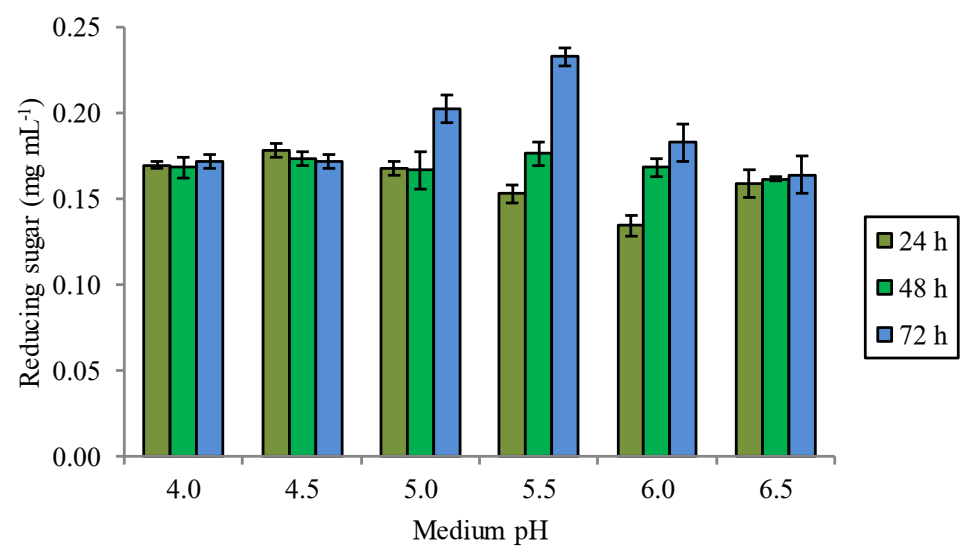

Fig. 4. Effect of medium $\mathrm{pH}$ on hydrolysis of alkali-treated OPEFB using A. niger. 


\section{Conclusion}

Enzymatic hydrolysis for depolymerization of both untreated and pre-treated OPEFB performed, with the aid of cellulase generated by isolate A. niger InaCC F98. The optimum process was achieved at $40{ }^{\circ} \mathrm{C}$, while the $\mathrm{pH}$ of medium differed between substrates, namely $\mathrm{pH} 5.0$ for untreated OPEFB and $\mathrm{pH} 5.5$ for pretreated OPEFB. This condition could produce reducing sugar at $13.01 \mathrm{mg} \mathrm{mL}^{-1}$ for untreated OPEFB and $1.16 \mathrm{mg} \mathrm{mL}^{-1}$ for pre-treated OPEFB after $72 \mathrm{~h}$ of incubation.

The authors would like to thank the Korea Institute of Science and Technology (KIST) for providing research funding in the form of KIST school partnership project 2019 (Number: B797/IPT.2/OT.01/II/2019).

\section{References}

1. N. Sarkar, S. K. Ghosh, S. Bannerjee, K. Aikat, Renew. Energ. 37,1:19-27, (2012). https://doi.org/10.1016/j.renene.2011.06.045

2. A. Mulyaningtyas and W. B. Sediawan, Biocatal. Agric. Biotechnol. 21:101292(2019). https://doi.org/10.1016/j.bcab.2019.101292

3. A. Rodríguez, L. Serrano, A. Moral, A. Pérez, L. Jiménez, Bioresour. Technol. 99,6:1743-1749(2008). https://doi.org/10.1016/j.biortech.2007.03.050

4. A. Verardi, I. De Bari, E. Ricca, V. Calabrò, Bioethanol. In Tech:. (2012).p.290. https://www.intechopen.com/books/bioethanol/hydrolysis-of-lignocellulosicbiomass-current-status-of-processes-and-technologies-and-future-perspe

5. P. Lenihan, A. Orozco, E. O’neill, M. Ahmad, D. Rooney, G. Walker, Chem. Eng. J. 156,2:395-403(2010). https://doi.org/10.1016/j.cej.2009.10.061

6. A. M. J. Kootstra, H. H. Beeftink, E. L. Scott, J. P. Sanders, Biochem. Eng. J. 46,2:126-131(2009). https://doi.org/10.1016/j.bej.2009.04.020

7. J. Kaur, B. S. Chadha, B. A. Kumar, H. S. Saini, Bioresour. Technol. 98,1:7481(2007). https://doi.org/10.1016/j.biortech.2005.11.019

8. H.-Q. Liu, Y. Feng, D.-Q. Zhao and J.-X. Jiang, Biodegradation, 23:465-472, (2012). https://doi.org/10.1007/s10532-011-9525-6

9. J.J. Abdullah, D. Greethan, N. Pensupa, G.A. Tucker, C. Du, J.Fundam. Renew. Energy Appl. 6,3:1-10(2016).

https://www.longdom.org/archive/jfra-volume-6-issue-3-year-2016.html

10. J. Itelima, A. Ogbonna, S. Pandukur, J. Egbere, A. Salami, (2013). http://hdl.handle.net/123456789/871

11. Y. Sudiyani, J. Waluyo, E. Triwahyuni, D. Burhani, Muryanto, P. Primandaru, et al., Optimization pretreatment condition of sweet sorghum bagasse for production of second generation bioethanol. AIP Conference Proceedings. 1803,1:020015(2017). https://doi.org/10.1063/1.4973142

12. A. Sridevi, G. Narasimha, G. Ramanjaneyulu, K. Dileepkumar, B. R. Reddy, P. S. Devi, 3 Biotech. 5,883-892, (2015). https://doi.org/10.1007/s13205-015-0284-7

13. P. Pathak, N. K. Bhardwaj, A. K. Singh, Appl. Biochem. Biotechnol. 172:37763797(2014). https://doi.org/10.1007/s12010-014-0758-9

14. K.M. Grigoryan, L.L. Hakobyan, Proceedings of The Yerevan State University, 3, 23-28, (2015). http://eph.am/science/en/1449232721 
15. M. Remaz, A. Abd Elrsoul, A. Shami Elhaj, Jordan J. Biol. Sci. 11:31-36(2017). http://jjbs.hu.edu.jo/files/v11n1/Paper Number 5m.pdf 